\title{
Could the vulnerable great Capricorn beetle benefit from the introduction of the non-native red oak?
}

\author{
Andrzej Oleksa ${ }^{1}\left(\mathbb{D} \cdot\right.$ Tomasz Klejdysz $^{2}$
}

Received: 20 November 2016 / Accepted: 25 March 2017 / Published online: 6 April 2017

(C) The Author(s) 2017. This article is an open access publication

\begin{abstract}
Introduced plants are often identified as the major conservation concern worldwide, however, they also may offer conservation benefits, among others, provide habitat and/or food resources to protected animals. Here we aimed to assess the ability of the great Capricorn beetle Cerambyx cerdo, a highly specialised species associated with mature oaks, to use non-native red oak Quercus rubra as a host plant. To test which factors influenced oak colonisation, we surveyed native and non-native oaks in 'Nowosolska Dolina Odry', a site within the 'Natura 2000' network (Western Poland). The beetle was detected in 34 native oaks (10.9\% of examined trees), demonstrating clear preferences for trees in a more open environment. Comparison of observed numbers of occupied oaks and values expected from their random colonisation showed that C. cerdo avoided non-native red oaks. Logistic regression revealed that variables with the greatest predictive importance for $C$. cerdo occurrence were canopy extent around the tree and trunk diameter, followed by an autocovariate (distance-weighted number of occupied trees in the neighbourhood of the target tree). Oak species was a poor predictor of tree occupancy, however, it added considerably to the
\end{abstract}

Electronic supplementary material The online version of this article (doi:10.1007/s10841-017-9978-y) contains supplementary material, which is available to authorized users.

Andrzej Oleksa

olek@ukw.edu.pl

1 Institute of Experimental Biology, Kazimierz Wielki University, Powstańców Wielkopolskich 10, 85-090 Bydgoszcz, Poland

2 Department of Entomology, Institute of Plant ProtectionNational Research Institute, Władysława Węgorka 20, 60-318 Poznań, Poland predictive capability of the models when combined with the remaining variables. We argue that physicochemical properties of the wood and/or phloem and structure of the cortex may also influence colonisation of trees. Our results do not provide arguments for the introduction of non-native oaks to benefit $C$. cerdo. Instead, we recommend maintaining semi-open conditions around host trees and high density of old oaks in the landscape.

Keywords Non-native plants · Saproxylic organisms · Habitats Directive $\cdot$ Habitat preferences, Cerambycidae Cerambyx cerdo $\cdot$ Veteran trees $\cdot$ Northern red oak · Quercus rubra

\section{Introduction}

Introduced, non-indigenous plants are often identified as one of the major conservation concerns worldwide (Vitousek et al. 1996). Their effect on the native biota may be related to a number of phenomena, such as altering vegetation communities and disturbance regimes, destabilisation of existing trophic interconnections and nutrient cycling in the ecosystem (Levine et al. 2003). There is increasing evidence that alien plants significantly affect animal communities, contributing to decreased fitness, abundance and diversity of the resident species in invaded sites (Moroń et al. 2009; Vila et al. 2011; Lenda et al. 2013).

In some cases, however, introduced plants may also offer benefits to some species (Davis et al. 2011; Gleditsch and Carlo 2011; Schlaepfer et al. 2011). These include, among others, providing habitat or food resources to animals of conservation interest. For example, pollinators may use alien plants as an additional source of food due to their increased availability in disturbed habitats (Williams et al. 
2011). In some cases, introduced plants may be even more attractive to resident herbivores than native plants (Parker and Hay 2005; Mokotjomela et al. 2013; Bartomeus et al. 2016). On the other hand, a larger number of studies have revealed the opposite effect, i.e., the exotic plant species are less attractive to native herbivores in comparison with their original host plants (e.g., Sugiura 2010; Harvey et al. 2012; Morandin and Kremen 2013; Litt et al. 2014; Kirichenko and Kenis 2016) or their consumption results in reduced fitness (Tallamy et al. 2010). These contradictory results indicate that the usage of non-indigenous plants as novel food by animals may be influenced by variation in life history traits and/or coevolution with related plant species. When herbivores do not share an evolutionary history with a relative of introduced plant characterised by similar properties, they may not be able to use the novel plant as food (Harvey et al. 2012). The possibility to use exotic plants also depends on the diet breadth of herbivores and it might be expected that generalists are more likely than specialists to include novel hosts in their diets (Bertheau et al. 2010). From this perspective, it could be hypothesised that species of conservation interest which typically show a high degree of specialisation (Mckinney 1997), may include a narrower range of novel hosts in their diet than species with wider preferences. Therefore, herbivores of conservation interest may not benefit from introduced plants as much as their less specialised relatives. Indeed, results showing that vulnerable and highly-specialised herbivores can switch to introduced plants are almost impossible to find in the literature, contrary to the numerous examples showing exploitation of the novel food resources (especially, edible plant materials, like fruits or nectar) by generalists (e.g., Gleditsch and Carlo 2011, 2014; Bartomeus et al. 2016).

In this work, we aimed to assess the ability of the great Capricorn beetle, a vulnerable and highly specialised species strictly associated with mature oaks, to use a nonnative host plant. For this purpose, we surveyed the occurrence of Cerambyx cerdo in the area where both native and introduced oak species grow in close proximity. To date, reports on the feeding of the great Capricorn beetle on oaks other than native European oaks (especially pedunculate oak Quercus robur in areas outside the Mediterranean) are rare, despite the fact that introduced species of oaks are relatively common. This applies in particular to the northern red oak Quercus rubra, a tree of Northern-American origin, which has become fairly widespread in Europe since its introduction in the late seventeenth century as an ornamental tree and in silviculture (Woziwoda et al. 2014b; Miltner and Kupka 2016). It is difficult to judge whether a paucity of data on the occurrence of $C$. cerdo on the red oak results from the real avoidance of the non-indigenous oak or is due to researcher's bias towards native oaks. We hope that our results could shed light on this issue and allow for a better understanding of habitat requirements of the great Capricorn beetle.

\section{Methods}

\section{Studied species}

The great Capricorn beetle $C$. cerdo is one the largest of the European beetle species (body length $28-55 \mathrm{~mm}$ ). It occurs in warmer regions of the Western Palearctic, from Algeria to southern Sweden and from Spain to Caucasus. The species is strongly associated with oaks, however, some other trees (chestnut Castanea sativa, elm Ulmus spp., common walnut Juglans regia) are also anecdotally mentioned in the literature as occasional hosts (Sláma 1998). It is often claimed that in Central Europe the species clearly prefers $Q$. robur, however, it could feed on some other oak species, including sessile oak Quercus petraea, red oak $Q$. rubra and scarlet oak Quercus coccinea (Neumann and Malchau 2010 and references cited therein). In the Mediterranean, the main hosts are holm oak Quercus ilex L. and cork oak Quercus suber L. (Torres-Vila et al. 2016). The beetle develops only on living trees as the larvae need fresh wood to feed on. Their feeding results in the creation of galleries in the trees, later used as habitats by other species, so that their activity greatly enhances biodiversity in tree ecosystems. As a result the species can be regarded as an ecosystem engineer (Buse et al. 2008a). Therefore, C. cerdo could serve as an umbrella species for protection of old-growth oaks and their associated fauna of saproxylic organisms (i.e., organisms dependent on wood decay, Speight 1989), which means that efforts to improve habitat conditions for C. cerdo have a positive effect on an entire assemblage of threatened insects (Buse et al. 2008b). C. cerdo is considered a threatened species in most of its entire European range and has long been protected under the Bern Convention, catalogued in Annexes II and IV of the EU Habitats Directive and classified as a near-threatened species by the European Red List of Saproxylic Beetles (Nieto and Alexander 2010).

Trees investigated in this study, pedunculate oak $Q$. robur and sessile oak $Q$. petraea, are species of oaks native to most of Europe. The northern red oak $Q$. rubra is a tree introduced to Europe from the eastern part of the USA and Canada (Woziwoda et al. 2014b; Miltner and Kupka 2016). Its ecological spectrum covers deciduous and mixed forests. In Central Europe, due to low habitat demands it easily spreads in human-modified habitats, such as fallow lands, along roadsides and railroads (Riepšas and Straigyte 2008; Woziwoda et al. 2014b). Quercus rubra contributes to the reduction of the biodiversity of the forest understorey, mainly due to very slow decomposition of fallen leaves 
which impede the growth of other plants and changes in light conditions as a result of more closed canopy stands (Chmura 2013; Woziwoda et al. 2014a).

\section{Area under study}

The study covered the southern part of the special area of conservation (SAC) 'Nowosolska Dolina Odry' (SAC code PLH080014, Fig. 1) within the European 'Natura 2000' network. This area is located in the central part of the Odra (Oder) river valley in western Poland. This part of the valley is a large basin located at an altitude of approx. $90 \mathrm{~m}$ above the sea level. The flow of the Odra river through the valley is tortuous, and there are numerous oxbow lakes as remnants of its past riverbeds. At present, a significant part of the bottom of the valley is used as arable land because of the fertile alluvial soils. In the vicinity of the Oder there are numerous watercourses and ponds, wet meadows, remnants of alluvial forests (habitat 91E0: alluvial forests with willow, poplar, alder and ash-Salicetum albo-fragilis,
Populetum albae, Alnenion glutinoso-incanae; habitat 91F0: alluvial forest with oak, elm and ash-Ficario-Ulmetum) and relic clusters of old oaks within fields and meadows. The largest oak group in the study area grows in a $2 \mathrm{~km}$ long avenue called 'Trakt Pruski' ('Prussian Route'). Oaks in this avenue (both pedunculate oak $Q$. robur and red oak $Q$. rubra) were planted at the turn of eighteenth and nineteenth century. The Eastern half of the route gradually ceased to be used in the last 70 years, so much of it has overgrown due to the natural succession of the vegetation of scrub or forest. In addition, a number of old oaks also occur along the Odra, where they were planted to strengthen flood embankments.

\section{Field methods}

Field works was performed in the first half of July in 2016. For the study, we surveyed oaks growing on transects along selected roads and pathways, including the described above 'Trakt Pruski' avenue and pathways on river embankments.

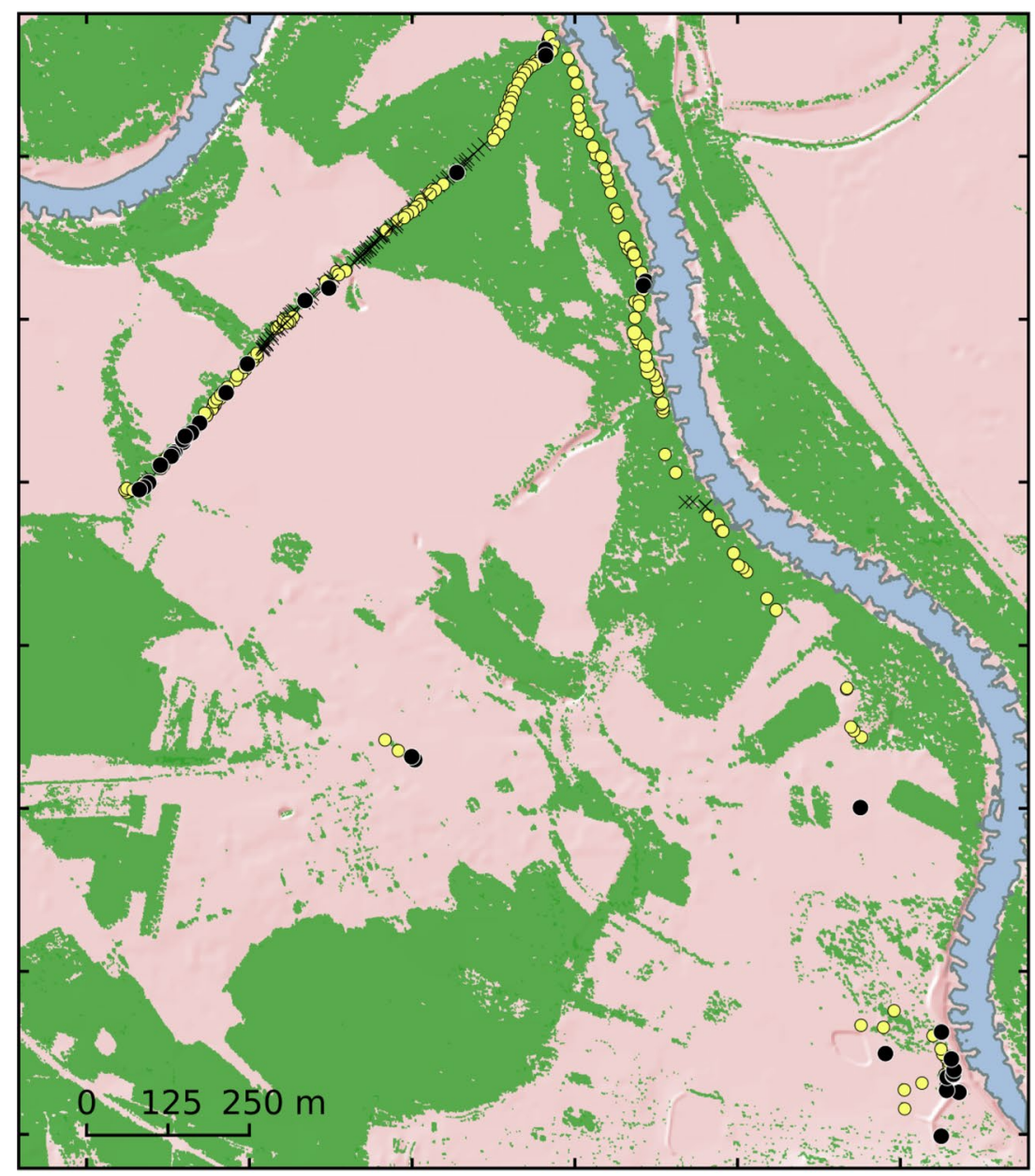

Studied oaks

- native oak with $C$. cerdo

- native oak without $C$. cerdo

$x$ non-native red oak

\section{Land cover}

area covered by tree canopies area without tree canopies surface waters (Odra river)

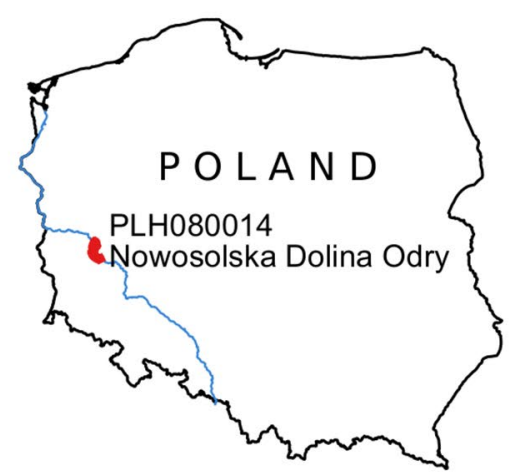

Fig. 1 Map of the study area showing the location of and species identity of surveyed oaks, their occupancy by $C$. cerdo and distribution of tree canopies around them 
Also, the largest clusters of pasture oaks outside avenues were included. Transects for the study were selected to provide trees with possibly diverse characteristics, including trunk girth, sun exposure and oak species (two native oak species, $Q$. robur and $Q$. petraea vs. alien red oak $Q$. rubra). Based on results of previous studies on the species' preferences (Buse et al. 2007; Albert et al. 2012), young oaks $(\mathrm{DBH}<20 \mathrm{~cm})$ were assumed as not suitable for the beetle development and omitted during the inventory. For each surveyed tree, we recorded in the field its coordinates with a precise GPS receiver (Pathfinder Pro XT, Trimble, Sunnyvale, CA, USA) and described in terms of tree species, DBH ('diameter at breast height', i.e., trunk girth measured at 1.3 metres above ground), tree health using a 5 point scale (Pacyniak 1992) and the presence/absence of C. cerdo (Table 1). Trees were considered occupied if the signs of larval feeding were recorded. In particular, because the galleries gnawed by larvae in the hard oak wood can survive for a very long time, we paid special attention to the signs of the recent activity of the larvae, i.e. fresh bores with bright wood shavings and exit holes of adult beetles (Stachowiak 2013).

\section{Statistical analysis}

In the study, we aimed to assess the ability of the great Capricorn beetle to use non-native red oaks as a host tree for larval development. For this purpose, we used two approaches, i.e., comparison of available and used amount of the habitat and multiple regression modelling of the effects of tree variables on the beetle occurrence.

First, we wanted to find out whether the great Capricorn beetle inhabits oak trees at random (due to their availability) or exhibits preferences for certain oak species. Therefore, the occurrence of $C$. cerdo with respect to oak species was compared with a random sample model. Occurrences of $C$. cerdo were randomly drawn from the overall pool of potential host trees (=habitat availability) and the resulting frequencies per oak species were compared with the observed ones (=actual habitat usage). Since the species avoids thin young trees and colonisation in central Europe appears exclusively on oaks larger than $60 \mathrm{~cm}$ in DBH (Buse et al. 2007; Albert et al. 2012), we performed the analysis exclusively for thicker trees $(\mathrm{DBH} \geq 60 \mathrm{~cm})$. Expected frequencies and standard deviations were generated from 10,000 random samples using $\mathrm{R}$ statistical software ver. 3.3.2 (R Core Team 2016). The frequency distribution of these random samples was in all cases approximately normally distributed. Hence we used the common Z-transformation $[Z=(x-\mu) / \sigma]$ to infer the probability levels for the observed values from the standard normal distribution. $Z$-scores above 2 or below -2 indicate significant $(\mathrm{p}<0.05)$ deviations of the observed value $x$ from expectation $\mu$.

Next, a multiple regression was conducted to predict the probability of $C$. cerdo occurrence in oaks in relation to tree variables. Since we expected our C. cerdo occurrence data to be spatially autocorrelated (tested with the Moran's I statistics in 'SAM' ver. 4.0, Rangel et al. 2010, Supplementary material 1), we used a regression approach designed specifically for analysis of autocorrelated data. In this analysis, we used generalised linear models (GLMs) with binomial distribution and logit link function (logistic regression) and incorporated spatial autocorrelation by the inclusion of an autologistic term ('autocovariate'). An autocovariate describes the response (in our data, presence/ absence of the species) at a given site (in our data, tree) as a function of the responses at neighbouring sites (trees). Because the probability of $C$. cerdo presence in a certain tree may depend on the occupation of surrounding trees, the autocovariate term was calculated as the distance-weighted number of occupied trees in the vicinity of the target tree. We used the 'spdep' ver. 0.6-8 R package (Bivand and Piras 2015) to calculate autocovariates at several assumed neighbourhood sizes (all sizes from 50 to $1000 \mathrm{~m}$ at $50-\mathrm{m}$ intervals, sizes from 1,000 to 2,000 at $500 \mathrm{~m}$ intervals) using two types of distance-weighting scheme: by inverse distance or by the square of the inverse distance. Then values derived from all 44 combinations of neighbourhood

Table 1 Explanatory variables used in this study to explain presence/absence of $C$. cerdo in studied trees

\begin{tabular}{|c|c|}
\hline Variable & Description \\
\hline DBH & $\begin{array}{l}\text { Diameter of tree trunk measured at breast height }(130 \mathrm{~cm}) \text {; average from two perpendicular measurements of the trunk. } \\
\text { Continuous, in cm }\end{array}$ \\
\hline HEALTH & $\begin{array}{l}\text { Tree health status measured in } 5 \text { point scale (Pacyniak 1992): } 1 \text {-trunk and crown healthy; } 2 \text {-decay and hollows possible, } \\
\text { up to } 25 \% \text { of crown damaged or loss; } 3-25-50 \% \text { damaged or loss; } 4-50-75 \% \text { damaged or loss; } 5 \text {-above } 75 \% \text { damaged } \\
\text { (loss) or a dead tree. Trees with health status } 1 \text { by definition are not hollow; trees with poor health could contain cavities }\end{array}$ \\
\hline OAK.NATIVE & Three oak species coded as binary variable: 1 (native $Q$. robur, $Q$. petraea) or 0 (alien, $Q$. rubra) \\
\hline CANOPY & Canopy cover around tree trunks, estimated for an assumed radius from aerial imagery. Proportion, from 0 to 1 \\
\hline AUTCOVARIATE & $\begin{array}{l}\text { Autocovariate of dependent variable, calculated as the distance-weighted number of occupied trees in the neighbourhood of } \\
\text { the target tree }\end{array}$ \\
\hline
\end{tabular}

See "Methods" section for details on computation of CANOPY and AUTCOV 
sizes and weighting schemes were submitted as explanatory variables to $C$. cerdo occurrence regression models. The model's Akaike information criterion (AIC) was used to identify the combination of neighbourhood size and the weighting scheme that resulted in the best fit with the presence of the studied species. For model selection, R package 'MuMIn' ver. 1.15.6 was used (Bartoń 2015). An analogous approach was employed to find the most appropriate radius for canopy analysis, i.e., canopy coverage was recognised using the semi-automatic classification plugin (Congedo 2016) in QGIS ver. 2.18.0 (QGIS Development Team 2016) based on current aerial imagery (geoportal.gov.pl) for 11 increasing radii (10 values from 10 to $100 \mathrm{~m}$ at $10-\mathrm{m}$ intervals and $200 \mathrm{~m}$ ) and subjected as explanatory variables to GLMs with the species presence/absence as the dependent variable. Again, model selection based on AIC served to choose canopy estimate at the most relevant radius. It should be mentioned here that AIC pointed to $30 \mathrm{~m}$ as the most appropriate radius for CANOPY and neighbourhood of $250 \mathrm{~m}$ and inverse distance weighting scheme as best settings for AUTOCOVARIATE calculations (for detailed results, see Supplementary material 2 and 3).

So derived CANOPY and AUTOCOVARIATE variables along with DBH and OAK.NATIVE (Table 1) were used to build the final GLM model explaining the presence/absence of $C$. cerdo in relation to tree characteristics. In order to develop an optimal set of explanatory variables responsible for the occurrence of $C$. cerdo, a comparison of all possible GLMs was performed to find the most parsimonious model. The selection of final variables in the GLM model was based on AIC, which tries to balance model fit and parsimony and penalises candidate models for including variables that do not add explanatory power to the result. We used AIC weights $\left(\omega_{\mathrm{i}}\right)$ to generate weighted model-averaged parameter estimates. Model selection and model averaging were carried out in "MuMIn" ver. 1.15.6 R package (Bartoń 2015). Visualisation of regression models was done using 'visreg' ver. 2.3-0 R package (Breheny and Burchett 2016).

In multiple regression, collinearity between predictor variables may confound their individual effects. Therefore, prior to regression analysis, we calculated Pearson correlation coefficients for pairwise combinations of independent variables (Supplementary material 4). For all examined variables pairs, Pearson's correlation coefficients ranged between -0.37 and 0.36 , i.e., below the level that could result in collinearity. Correlation between HEALTH and DBH was relatively high $(0.364, p<0.0001)$ and we were not sure about the nature of the relationship between HEALTH and the dependent variable (presence/absence of C. cerdo)-it seemed likely that the poor state of health was not the cause but the consequence of the C. cerdo occurrence. Therefore, the HEALTH variable was omitted while all other independent variables were included in the regression models.

Differences between native and non-native oak species in tree characteristics were tested with the Mann-Whitney $U$-test. The statistical analyses, unless otherwise specified, were performed with $\mathrm{R}$ ver. 3.3.2 (R Core Team 2016).

\section{Results}

In total, 311 oak trees were examined, including 90 alien red oaks Q. rubra and 221 native oaks (28.9 and $71.1 \%$ of all examined oaks, respectively). Among native oaks, there were 214 pedunculate oaks $Q$. robur and seven sessile oaks $Q$. petraea (68.8 and $2.3 \%$ of all oaks, respectively). Since the number of observations of $Q$. petraea accounted for a very small fraction of all cases, in regression analysis we treated all native oaks $(Q$. robur $+Q$. petraea $)$ as one category.

The presence of $C$. cerdo was confirmed in 34 oaks (10.9\% of all examined oaks), in most cases growing in open habitats, however, the distribution of the beetle was not random with respect to oak species. All observations of the beetle were from native oaks (one observation in $Q$. petraea and 33 in $Q$. robur) and the smallest $\mathrm{DBH}$ of an occupied tree was $60 \mathrm{~cm}$. We failed to confirm the presence of the species in any of the surveyed red oaks. Comparison of observed numbers of occupied thick oaks $(\mathrm{DBH} \geq 60 \mathrm{~cm}$, $\mathrm{N}=250$ ) and values expected from the random sample model (random colonisation of oaks, depending only on their availability) showed that $C$. cerdo occurred on nonnative red oaks less often than by chance $(Z=-3.25$, $p=0.001$, Table 2).

The influence of oak species on the occurrence of $C$. cerdo proved to be much less important after taking into account the effect of other explanatory variables in logistic regression analysis. First of all, oaks inhabited by $C$. cerdo were significantly thicker than unoccupied oaks (medians 100 and $82 \mathrm{~cm}$, respectively, $p(U)=0.0001$ ) but there was also a significant difference in DBH between introduced red oaks and native oaks, with red oaks usually smaller

Table 2 Differences between observed and expected occupancies of C. cerdo in thick oaks $(\mathrm{DBH} \geq 60 \mathrm{~cm})$ belonging to different species

\begin{tabular}{lcccrl}
\hline Oak species & $\begin{array}{l}\text { Total } \\
\text { number of } \\
\text { trees }\end{array}$ & $\begin{array}{l}\text { Trees } \\
\text { with } C . \\
\text { cerdo }\end{array}$ & $\begin{array}{l}\text { Expected num- } \\
\text { ber of occupied } \\
\text { trees (SD) }\end{array}$ & $Z$ & $p$ \\
\hline Q. petraea & 5 & 1 & $0.68(0.77)$ & 0.41 & 0.68 \\
Q. robur & 191 & 33 & $25.99(2.32)$ & 3.02 & $\mathbf{0 . 0 0 3}$ \\
Q. rubra & 54 & 0 & $7.32(2.25)$ & -3.25 & $\mathbf{0 . 0 0 1}$ \\
Total & 250 & 34 & & & \\
\hline
\end{tabular}

Significant values are shown in bold 
than native oaks (medians 65.5 and $88.0 \mathrm{~cm}$, respectively, $p(U)=0.0001$, Fig. 2). Next, although CANOPY showed no differences between native and non-native oaks (medians 0.81 and $0.83, p(U)=0.9)$, non-native oaks were usually more distant in relation to sources of colonisation than native oaks (AUTOCOVARIATE medians 0.021 and 0.023, $p(U)=0.02$ ).

Analysis of logistic regression revealed that all examined explanatory variables influenced the probability of C. cerdo occurrence, however, their importance relative to predictive reliability showed considerable differences (Table 4). The variables with the greatest predictive importance were CANOPY and DBH (for both variables, relative importance was equal to 1.00), followed by AUTOCOVARIATE (relative importance 0.98). It means that thick trees growing in a more open environment and not too far from other occupied trees were colonised by $C$. cerdo more often than thin trees surrounded by dense vegetation and distant from to colonised trees (Fig. 3). Compared with these three variables, the effect of oak species (OAK. NATIVE relative importance equal to 0.86 ) turned out to be statistically insignificant when average parameter estimates were calculated using Akaike weights (Table 4). On the other hand, although the OAK.NATIVE variable alone was a poor predictor tree occupancy, it added considerably to the predictive capability of the models when it was combined with CANOPY, DBH and AUTOCOVARIATE, as indicated by the large difference in AIC weights between the highest ranked model and subsequent model ( 0.836 and 0.139 , respectively, Table 3 ).

\section{Discussion}

Our results did not demonstrate that the vulnerable great Capricorn beetle could benefit from the introduction of the non-native red oak. Despite surveying a relatively large number of the introduced oaks sharing common ground with native oaks, we have not confirmed the beetle presence in the introduced red oaks. In this respect, our results agree with the claims of other researchers that in the Central Europe the species is mainly associated with the native pedunculate oak Q. robur (Sláma 1998; Neumann and Malchau 2010; Stachowiak 2013). Thus, the data presented here do not provide arguments for the introduction of invasive red oak into European ecosystems. There are also other reasons against spreading of this non-native tree in Europe. The introduction of red oak can dramatically change the litter and organic matter decomposition rate, nutrient cycling and availability, thus threatening ecosystem functioning and services (Bonifacio et al. 2015). Since Q. rubra is a highly competitive species both as a mature tree and in the



Fig. 2 Boxplots showing distribution of variables used to describe oaks investigated in this study. The band near the middle of the box is the median, the notch is the $95 \%$ confidence interval around the median, the vertical size of the box is the interquartile range (IQR)
CANOPY

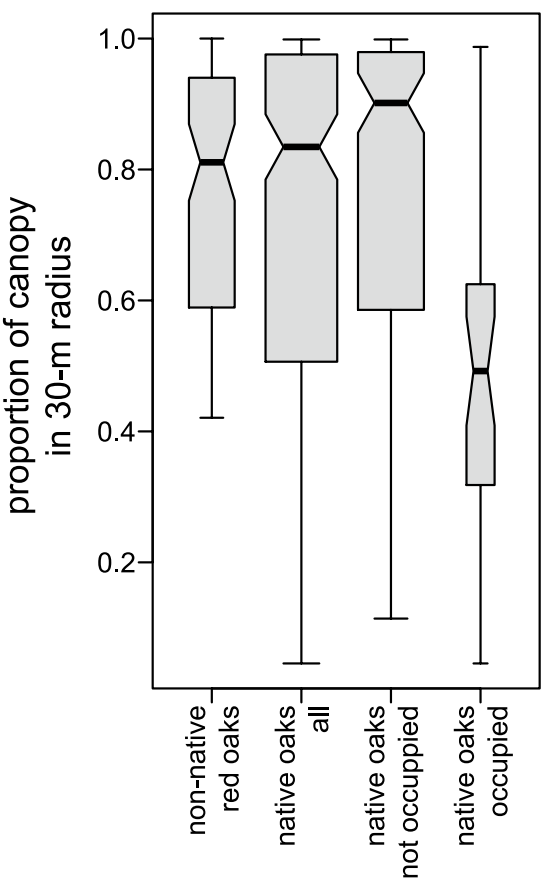

AUTOCOVARIATE

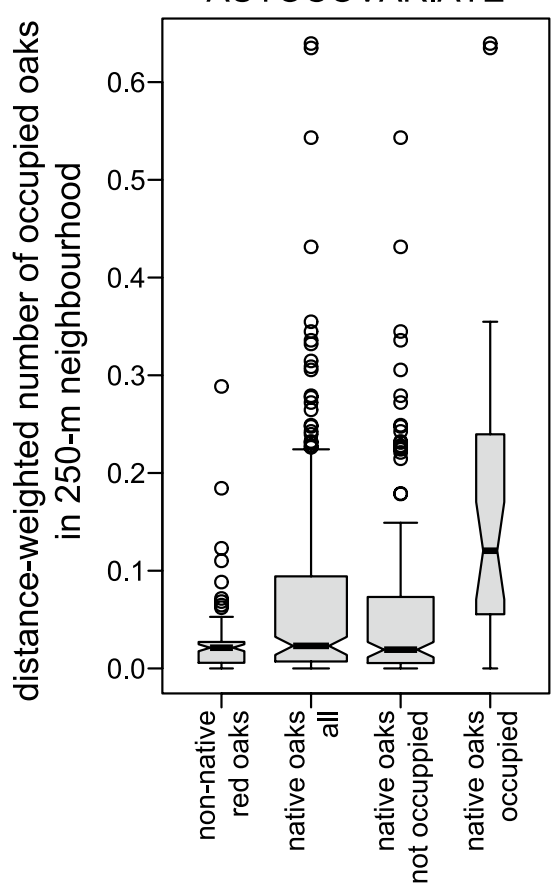

or $50 \%$ of the data, whiskers indicate $1.5 \times \mathrm{IQR}$ and dots observations outside this range ('outliers'); box width is proportional to the number of observations in each class 


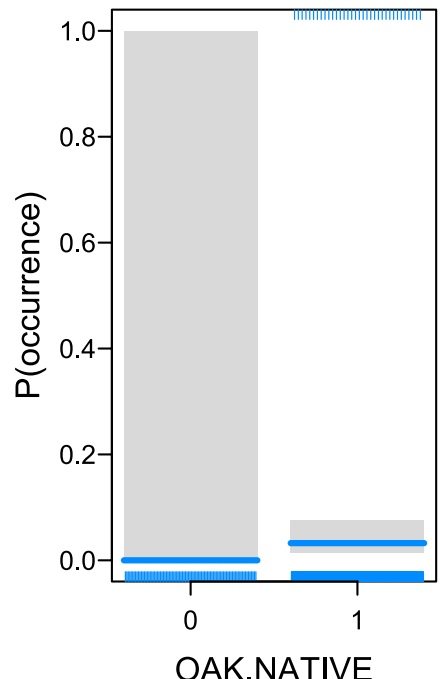

OAK.NATIVE

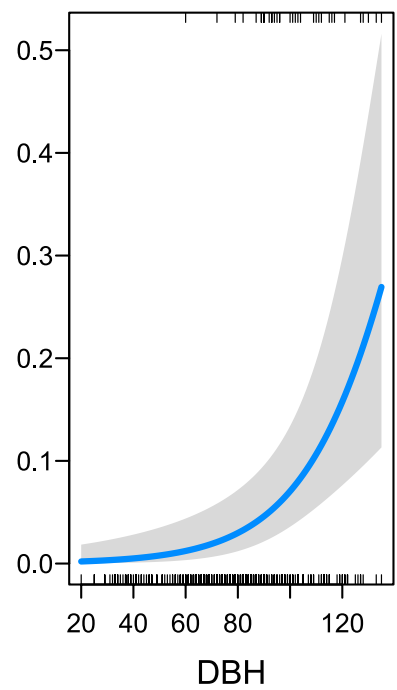

$\mathrm{DBH}$
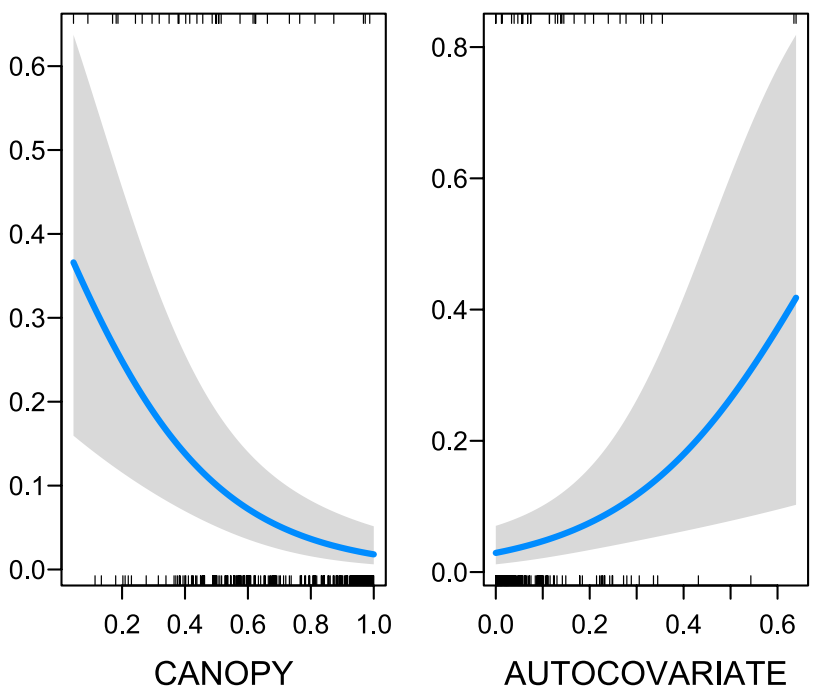

and autocovariate (distance-weighted number of occupied trees in a 250-m neighbourhood). Regression line and 95\% confidence bands for the top model shown in Table 3

On the other hand, our results do not prove that the red oak is absolutely unsuitable as a host tree for the studied beetle. Although the colonisation of oak was not random with respect to oak species, results of logistic regression indicated that the relative importance of oak species was small in comparison with the other tree variables, such as trunk diameter, canopy coverage around trees and their isolation from other occupied trees. Our results are not conclusive in this regard due to the peculiarities of the system under study. While the optimal study design for testing the impact of tree species on the occurrence of the beetle should consist of group of trees showing differences in one examined trait (i.e., tree species) but uniform in term of other variables, in our research we had to rely on the analysis of an existing system, in which red oaks were generally smaller than native oaks. Therefore, our results can be interpreted in either of two ways. One is that the non-native red oak has some features that make it unsuitable for the great Capricorn beetle and the other possible interpretation is that our studied red oaks were simply too thin to become occupied. To resolve this dilemma, further studies at additional field sites would be needed. The main obstacle to the realisation of such a research, however, may be the availability of sites occupied by $C$. cerdo where both native and introduced oaks of similar sizes are abundant since the introduced red oaks are usually less durable and younger than native oaks. Pedunculate oak is known for its longevity and the large dimensions that it reaches. For example, in Poland numerous individuals of $Q$. robur reach $\mathrm{DBH}$ of $3 \mathrm{~m}$ and more, while there is not a single red oak thicker than $1.7 \mathrm{~m}$ (PMTR Team 2016). Also in our study, the largest form of seedlings or small saplings, it significantly reduces native plant species richness and abundance, contributing to the reduction of biodiversity in forest communities both in old-growth and in secondary (post-agricultural) forests (Chmura 2013; Woziwoda et al. 2014a). 
Table 4 AIC-weighted model-averaged parameter estimates generated from models of presence of $C$. cerdo in oak trees (Table 3)

\begin{tabular}{llrrll}
\hline & $\begin{array}{l}\text { Relative } \\
\text { variable } \\
\text { importance }\end{array}$ & Estimate & Adj. SE & $Z$ value & $\operatorname{Pr}(>|Z|)$ \\
\hline (Intercept) & & -18.20 & 969.65 & 0.02 & 0.99 \\
$\begin{array}{c}\text { AUTOCO- } \\
\text { VAR }\end{array}$ & 0.98 & 5.06 & 1.68 & 3.01 & $0.003^{* *}$ \\
CANOPY & 1.00 & -3.66 & 0.89 & 4.11 & $0.00004^{* * *}$ \\
DBH & 1.00 & 0.05 & 0.01 & 3.52 & $0.0004^{* * *}$ \\
TREE. & 0.86 & 16.16 & 1045.58 & 0.02 & 0.99 \\
NATIVE & & & & & \\
\hline
\end{tabular}

Signif. codes: 0 ‘***’ 0.001 ‘**’ 0.01

red oaks were in very poor health, indicating that achieving greater age and size is unlikely in this species.

Among the features of different oak species which may affect their potential use as host trees by $C$. cerdo, differences in chemical composition could play the most important role. In line with this expectation, oaks investigated in this study $(Q$. rubra and $Q$. robur) show remarkable differences in phenolic compounds found in the wood (Zarzyński 2009). Therefore, it might be hypothesised that the red oak is not occupied by $C$. cerdo because it could be too different in terms of chemical composition from European oaks to be considered as a suitable host tree. It is well established that the fitness of herbivores moving from one host to another decreases with the taxonomic distance between hosts, so specialised herbivores usually develop effective systems for identifying unsuitable host plants and their avoidance (Bertheau et al. 2010). For example, Pearse and Hipp (2009) in their study of insects on introduced and native oaks found that phylogenetic similarity to a native species predicts the level of insect occupancy on non-native oaks. However, it is unlikely that such differences explain the lack of colonisation of the red oak by C. cerdo in our research. This hypothesis is contradicted by the data on the molecular phylogeny of oaks (Manos et al. 1999), which divided the genus into four infrageneric groups: (Cerris- (Lobatae- (Protobalanus +Quercus sensu stricto))). According to this classification, Q. rubra belongs to section Lobatae, more closely related to section Quercus s.str. (containing $Q$. robur and $Q$. petraea) than to section Cerris (containing two the most important host trees in the Mediterranean, i.e. $Q$. suber and $Q$. ilex, Torres-Vila et al. 2016). It means that in Europe $C$. cerdo inhabits oaks from different sections, including species that are phylogenetically more distant than oaks included in our study. In this context, differences between $Q$. robur $Q$. petraea and $Q$. rubra should not be an obstacle to colonisation of the red oak.

In contrast, a trait that clearly differs the introduced red oak from its Central European congeneric species is the smoothness of the bark, which is composed of smooth areas separated by shallow furrows of rough fragments in $Q$. rubra and deep-fissured in $Q$. robur and $Q$. petraea. Previous results on the habitat preferences of $C$. cerdo showed that tree occupancy is affected, among others, by the thickness of fissures in the bark (Buse et al. 2007). It was suggested that the bark depth seems to be very important for successful egg development in C. cerdo, with female beetles preferentially using deep slits in the bark for oviposition (Döhring 1955 after; Buse et al. 2007). Similar selectivity for a particular type of bark during oviposition is also observed in other longhorn beetles (Naves et al. 2006).

In addition to the results on the occurrence of $C$. cerdo in various species of oaks, our study provided insight into habitat preferences of this vulnerable beetle, which may be important for the conservation of the species. As in previous studies (Buse et al. 2007; Albert et al. 2012), tree trunk diameter and the amount of shading around tree trunks proved to be the most important factors influencing oak colonisation by the beetle. The influence of the thickness of the trunk may operate in two ways. First, C. cerdo larvae are very large $(70 \mathrm{~mm}$ and more-Stachowiak 2013) so they require abundant food supply. Second, larger trunks may be warmer than smaller trunks because their large surface absorbs more solar radiation, which is important for a thermophilous species like $C$. cerdo (Buse et al. 2007; Albert et al. 2012). Enhanced heat intake may be particularly important in the spring if it allows feeding to start earlier. Close dependence of C. cerdo on solar radiation is also reflected in a greater number of exit holes on those parts of trunks that face south and west (Albert et al. 2012). Preference for sunexposed trees is a common phenomenon among many xylophagous and saproxylic insects, with many examples in the literature (Ranius and Jansson 2000; SverdrupThygeson and Ims 2002; Oleksa 2009; Vodka et al. 2009; Horák et al. 2012; Horák and Rébl 2013). Additionally, the intake of solar radiation depends strongly on canopy cover and understory around the trees. In our study, occupancy of trees was positively affected by habitat openness and oaks growing in pastures and in the avenue had a substantially higher incidence of $C$. cerdo than forests. Such a preference for more open habitats is typical for C. cerdo throughout its range (Luce 1997) and it was identified by previous studies as the main factor affecting the occurrence of $C$. cerdo at the level of trees and stands (Buse et al. 2007; Albert et al. 2012; Stachowiak 2013). Thus, the main objective of habitat management for $C$. cerdo is to reduce some understory vegetation that contributes to shading of tree trunks. Semi-open tree landscapes also harbour a great variety of other saproxylic organisms, including red-listed and protected taxa-for example, hermit beetles (Osmoderma eremita species complex) 
listed as priority species in the EU Habitat Directive (Ranius et al. 2005). Therefore, habitat management for C. cerdo will also be of great benefit to other taxa.

In our study, the distance-weighted number of occupied trees in the vicinity of the target tree came out as another highly significant variable affecting the distribution of $C$. cerdo in the studied area. Once again, these results are consistent with findings of previous studies (Buse et al. 2007). Spatial autocorrelation in tree occupancy reveals that $C$. cerdo is a poor disperser and chances of tree colonisation are highly dependent on nearby sources. A mark-releaserecapture study showed that most adults of $C$. cerdo were reluctant to undergo long dispersal flights, with most individuals remaining in the same tree for most (or all) of their lifetime (Torres-Vila et al. 2016). This kind of sedentary behaviour significantly impedes the colonisation of distant sites, hence assisted colonisation was proposed as a method for reducing the likelihood that this species will go extinct (Drag and Cizek 2015).

\section{Conclusions}

Our data support the current recommendation that maintaining semi-open conditions around host trees and high density of suitable oaks in the landscape is crucial for conservation of the great Capricorn beetle. We did not find evidence that the non-native red oak may be used as substitute host trees for C. cerdo. Taking into account that C. cerdo is a highly specialised species associated with large old oaks, this may result from the peculiarities of the studied red oaks, which generally achieved smaller trunk diameters than their native relatives. We hypothesised that physicochemical properties of the wood and/or phloem and different structure of the cortex, features that were not directly investigated in this study, may play some role in host selection. Experimental study of the impact of these variables on the colonisation of trees by $C$. cerdo opens up interesting prospects for further research.

\begin{abstract}
Acknowledgements We warmly thank Jacek Sauter, the mayor of Bytom Odrzański, for the encouragement to carry out this work. This research was supported by the Polish Ministry of Science and Higher Education through the statutory research funds received by the Faculty of Natural Science (Kazimierz Wielki University) and by the municipality of Bytom Odrzański.
\end{abstract}

Open Access This article is distributed under the terms of the Creative Commons Attribution 4.0 International License (http:// creativecommons.org/licenses/by/4.0/), which permits unrestricted use, distribution, and reproduction in any medium, provided you give appropriate credit to the original author(s) and the source, provide a link to the Creative Commons license, and indicate if changes were made.

\section{References}

Albert J, Platek M, Cizek L (2012) Vertical stratification and microhabitat selection by the Great Capricorn Beetle (Cerambyx cerdo)(Coleoptera: Cerambycidae) in open-grown, veteran oaks. Eur J Entomol 109:553-559.

Bartomeus I, Fründ J, Williams NM (2016) Invasive plants as novel food resources, the pollinators' perspective. In: Sol D, Weiss J (eds) Biological Invasions and Animal Behaviour. Cambridge University Press, Cambridge, pp 119-132

Bartoń K (2015) MuMIn: Multi-model inference. R package ver. 1.15.6. R Foundation for Statistical Computing. Vienna, Austria. http://CRAN.R-project.org/package=MuMIn

Bertheau C, Brockerhoff EG, Roux-Morabito G et al (2010) Novel insect-tree associations resulting from accidental and intentional biological "invasions": a meta-analysis of effects on insect fitness. Ecol Lett 13:506-515. doi:10.1111/j.1461-0248.2010.01445.x

Bivand R, Piras G (2015) Comparing implementations of estimation methods for spatial econometrics. J Stat Softw 63:1-36. doi:10.18637/jss.v063.i18

Bonifacio E, Petrillo M, Petrella F et al (2015) Alien red oak affects soil organic matter cycling and nutrient availability in low-fertility well-developed soils. Plant Soil 395:215-229. doi:10.1007/s11104-015-2555-9

Breheny P, Burchett W (2016) visreg: Visualization of Regression Models. R package ver. 2.3-0. R Foundation for Statistical Computing. Vienna, Austria. http://CRAN.R-project.org/ package $=$ visreg

Buse J, Schröder B, Assmann T (2007) Modelling habitat and spatial distribution of an endangered longhorn beetle-a case study for saproxylic insect conservation. Biol Conserv 137:372-381. doi:10.1016/j.biocon.2007.02.025

Buse J, Ranius T, Assmann T (2008a) An endangered longhorn beetle associated with old oaks and its possible role as an ecosystem engineer. Conserv Biol 22:329-337. doi:10.1111/j.1523-1739.2007.00880.x

Buse J, Zabransky P, Assmann T (2008b) The xylobiontic beetle fauna of old oaks colonised by the endangered longhorn beetle Cerambyx cerdo L innaeus, 1758 (Coleoptera $\dagger^{-}$: Cerambycidae). Mitt der Dtsch Ges für Allg Angew Ent 16:109-112.

Chmura D (2013) Impact of alien tree species Quercus rubra L. on understorey environment and flora: a study of the Silesian upland (Southern Poland). Pol J Ecol 61:431-442

Congedo L (2016). Semi-Automatic Classification Plugin Documentation. doi:10.13140/RG.2.2.29474.02242/1

Davis MA, Chew MK, Hobbs RJ et al (2011) Don't judge species on their origins. Nature 474:153-154. doi:10.1038/474153a

Döhring E (1955) Zur Biologie des Großen Eichenbockkäfers (Cerambyx cerdo L) unter besonderer Berücksichtigung der Populationsbewegungen im Areal. Zeitschrift für Angew Zool 45:251-373 (in German)

Drag L, Cizek L (2015) Successful reintroduction of an endangered veteran tree specialist: conservation and genetics of the Great Capricorn beetle (Cerambyx cerdo). Conserv Genet 16:267276. doi:10.1007/s10592-014-0656-2

Gleditsch JM, Carlo TA (2011) Fruit quantity of invasive shrubs predicts the abundance of common native avian frugivores in central Pennsylvania. Divers Distrib 17:244-253. doi:10.1111/j.1472-4642.2010.00733.x

Gleditsch JM, Carlo TA (2014) Living with aliens: effects of invasive shrub honeysuckles on avian nesting. PLoS ONE. doi:10.1371/journal.pone.0107120

Harvey KJ, Nipperess DA, Britton DR, Hughes L (2012) Australian family ties: Does a lack of relatives help invasive plants escape 
natural enemies? Biol Invasions 14:2423-2434. doi:10.1007/ s10530-012-0239-4

Horák J, Rébl K (2013) The species richness of click beetles in ancient pasture woodland benefits from a high level of sun exposure. J Insect Conserv 17:307-318. doi:10.1007/ s10841-012-9511-2

Horák J, Chumanová E, Hilszczański J (2012) Saproxylic beetle thrives on the openness in management: a case study on the ecological requirements of Cucujus cinnaberinus from Central Europe. Insect Conserv Divers 5:403-413. doi:10.1111/j.1752-4598.2011.00173.x

Kirichenko N, Kenis M (2016) Using a botanical garden to assess factors influencing the colonization of exotic woody plants by phyllophagous insects. Oecologia 182:243-252. doi:10.1007/ s00442-016-3645-y

Lenda M, Witek M, Skórka P et al (2013) Invasive alien plants affect grassland ant communities, colony size and foraging behaviour. Biol Invasions 15:2403-2414. doi:10.1007/s10530-013-0461-8

Levine JM, Vilà M, D’Antonio CM et al (2003) Mechanisms underlying the impacts of exotic plant invasions. Proc Biol Sci 270:775781. doi:10.1098/rspb.2003.2327

Litt AR, Cord EE, Fulbright TE, Schuster GL (2014) Effects of invasive plants on arthropods. Conserv Biol 28:1532-1549. doi:10.1111/cobi. 12350

Luce JM (1997) Cerambyx cerdo Linneaus, 1758. In: Helsdingen PJ, Willemse L, Speight MCD (eds) Background Information on Invertebrates of the Habitats Directive and the Bern Convention. Part I-Crustacea, Coleoptera and Lepidoptera. Nature and environment, vol 79. European Commission, Strasbourg

Manos PS, Doyle JJ, Nixon KC (1999) Phylogeny, biogeography, and processes of molecular differentiation in Quercus subgenus Quercus (Fagaceae). Mol Phylogenet Evol 12:333-349. doi:10.1006/mpev.1999.0614

Mckinney ML (1997) Extinction vulnerability and selectivity: combining ecological and paleontological views. Annu Rev Ecol Syst 28:495-516. doi: 10.1146/annurev.ecolsys.28.1.495

Miltner S, Kupka I (2016) Silvicultural potential of northern red oak and its regeneration-review. J For Sci 62:145-152. doi:10.17221/115/2015-JFS

Mokotjomela TM, Musil CF, Esler KJ (2013) Frugivorous birds visit fruits of emerging alien shrub species more frequently than those of native shrub species in the South African Mediterranean climate region. South African J Bot 86:73-78. doi:10.1016/j. sajb.2013.02.004

Morandin LA, Kremen C (2013) Bee preference for native versus exotic plants in restored agricultural hedgerows. Restor Ecol 21:26-32. doi:10.1111/j.1526-100X.2012.00876.x

Moroń D, Lenda M, Skórka P et al (2009) Wild pollinator communities are negatively affected by invasion of alien goldenrods in grassland landscapes. Biol Conserv 142:1322-1332. doi:10.1016/j.biocon.2008.12.036

Naves PM, De Sousa EM, Quartau JA (2006) Feeding and oviposition preferences of Monochamus galloprovincialis for certain conifers under laboratory conditions. Entomol Exp Appl 120:99104. doi:10.1111/j.1570-7458.2006.00430.x

Neumann V, Malchau W (2010) Cerambyx cerdo Linnaeus, 1758 Heldbock. Berichte des Landesamtes für Umweltschutz SachsenAnhalt 2:281-298 (in German)

Nieto A, Alexander KNA (2010) European red list of saproxylic beetles. Publications Office of the European Union, Luxembourg

Oleksa A (2009) Conservation and ecology of the hermit beetle Osmoderma eremita s.l. in Poland. In: Buse J, Alexander KNA, Ranius T, Assmann T (eds) Saproxylic beetles-their role and diversity in European woodland and tree habitats. Proceedings of the 5th Symposium and Workshop on the Conservation of Saproxylic Beetles. pp 177-188
Pacyniak C (1992) Najstarsze drzewa w Polsce [The oldest trees in Poland]. Przewodnik. PTTK "Kraj," Warszawa (in Polish)

Parker JD, Hay ME (2005) Biotic resistance to plant invasions? Native herbivores prefer non-native plants. Ecol Lett 8:959-967. doi:10.1111/j.1461-0248.2005.00799.x

Pearse IS, Hipp AL (2009) Phylogenetic and trait similarity to a native species predict herbivory on non-native oaks. Proc Natl Acad Sci U S A 106:18097-18102. doi:10.1073/pnas.0904867106

PMTR Team (2016) Polish Monumental Trees Register. http://www. rpdp.hostingasp.pl/. Accessed 15 Nov 2016

QGIS Development Team (2016). Quantum GIS Geographic Information System. Open Source Geospatial Foundation Project. http://qgis.osgeo.org

R Core Team (2016) R: a language and environment for statistical computing. R Foundation for Statistical Computing, Vienna, Austria. https://www.R-project.org/

Rangel TF, Diniz-Filho JAF, Bini LM (2010) SAM: a comprehensive application for Spatial Analysis in Macroecology. Ecography 33:46-50. doi:10.1111/j.1600-0587.2009.06299.x

Ranius T, Jansson N (2000) The influence of forest regrowth, original canopy cover and tree size on saproxylic beetles associated with old oaks. Biol Conserv 95:85-94. doi:10.1016/ S0006-3207(00)00007-0

Ranius T, Aguado L LO, Antonsson K et al (2005) Osmoderma eremita (Coleoptera, Scarabaeidae, Cetoniinae) in Europe. Anim Biodivers Conserv 28:1-44

Riepšas E, Straigytė L (2008) Invasiveness and ecological effects of red oak (Quercus rubra L.) in Lithuanian forests. Balt For $14: 122-130$

Schlaepfer MA, Sax DF, Olden JD (2011) The potential conservation value of non-native species. Conserv Biol 25:428-437. doi:10.1111/j.1523-1739.2010.01646.x

Sláma MEF (1998) Tesaříkovití - Cerambycidae České republiky a Slovenské republiky. [Longhorn Beetles - Cerambycidae of the Czech Republic and Slovak Republic.]. By the author, Krhanice (in Czech)

Speight M (1989) Saproxylic invertebrates and their conservation. Council of Europe, Strasbourg

Stachowiak M (2013) Kozioróg dębosz Cerambyx cerdo. In: Makomaska-Juchiewicz M, Baran P (eds) Monitoring gatunków zwierząt. Przewodnik metodyczny. Część II. GIOŚ, Warszawa, pp 349-366 (in Polish)

Sugiura S (2010) Associations of leaf miners and leaf gallers with island plants of different residency histories. J Biogeogr 37:237244. doi:10.1111/j.1365-2699.2009.02199.x

Sverdrup-Thygeson A, Ims RA (2002) The effect of forest clearcutting in Norway on the community of saproxylic beetles on aspen. Biol Conserv 106:347-357. doi:10.1016/S0006-3207(01)00261-0

Tallamy DW, Ballard M, D'Amico V (2010) Can alien plants support generalist insect herbivores? Biol Invasions 12:2285-2292. doi:10.1007/s10530-009-9639-5

Torres-Vila LM, Mendiola-Diaz FJ, Sánchez-González Á (2016) Dispersal differences of a pest and a protected Cerambyx species (Coleoptera: Cerambycidae) in oak open woodlands: a mark-recapture comparative study. Ecol Entomol. doi:10.1111/ een. 12355

Vila M, Espinar JL, Hejda M et al (2011) Ecological impacts of invasive alien plants: a meta-analysis of their effects on species, communities and ecosystems. Ecol Lett 14:702-708. doi:10.1111/j.1461-0248.2011.01628.x

Vitousek PM, DAntonio CM, Loope LL et al (1996) Biological invasions as global environmental change. Am Nat 84:468-478

Vodka S, Konvicka M, Cizek L (2009) Habitat preferences of oakfeeding xylophagous beetles in a temperate woodland: implications for forest history and management. J Insect Conserv 13:553-562. doi:10.1007/s10841-008-9202-1 
Williams NM, Cariveau D, Winfree R, Kremen C (2011) Bees in disturbed habitats use, but do not prefer, alien plants. Basic Appl Ecol 12:332-341. doi:10.1016/j.baae.2010.11.008

Woziwoda B, Kope D, Witkowski WJ (2014a) The negative impact of intentionally introduced Quercus rubra L. on a forest community. Acta Soc Bot Pol 83:39-49. doi:10.5586/asbp.2013.035

Woziwoda B, Potocki M, Sagan J, Zasada M (2014b) Commercial forestry as a vector of alien tree species-the case of Quercus rubra L. introduction in Poland. Balt For 20:131-141
Zarzyński P (2009) Identification and quantitative analysis of phenolic compounds naturally occuring in wood of selected European and exotic tree species. For Res Pap 70:27-39. (in Polish, English Summary) 